\title{
PERAN METODE PERTANGGALAN RADIOMETRIS DI BIDANG ARKEOLOGI DAN GEOLOGI
}

\author{
Wisjachudin Faisal \\ Pusat Teknolosi Akselerator dan Proses Bahan, BATAN \\ Jl. Babarsari Kotak Pos 6101 ykbb, Yogyakarta 55281 \\ Diterima 05 Mei 2009, diterima dalam bentuk perbaikan 08 Juni 2009, disetujui 29 Juni 2009
}

\begin{abstract}
ABSTRAK
PERAN METODE PERTANGGALAN RADIOMEIRIS DI BIDANG ARKEOLOGI DAN GEOLOGI. Telah dilakukan kajian tentang peranan metode pertanggalan radiokarbon pada bidang geologi dan arkeologi serta metode pertanggalan ${ }^{210} \mathrm{~Pb}$ di bidang geologi. Metode pertanggalan radiokarbon adalah metode pertanggalan dengan batasan umur maksimumnya adalah 45.000 tahun. Dalam kajian ini lebih ditinjau pada metode pertanggalan yang menggunakan proses sintesis karbon radioaktif $\left({ }^{14} \mathrm{C}\right)$ yang terkandung dalam cuplikan diubah menjadi benzena $\left({ }^{14} \mathrm{C}_{6} \mathrm{H}_{6}\right)$ lalu dicacah dengan pencacah kelip cair, dan pertanggalan ${ }^{210} \mathrm{~Pb}$ yaitu metode pertanggalan yang didasarkan pada pengukuran aktivitas ${ }^{210} \mathrm{~Pb}$. Pertanggalan ini khusus diperuntukkan bagi cuplikan sedimen, dan batasan umur maksimumnya adalah 150 tahun. Beberapa cuplikan lingkungan di sekitar situs arkeologi maupun geologi telah berhasil dilakukan analisis nilai umurnya dengan metode pertanggalan radiokarbon. Pertanggalan radiokarbon dapat juga memberikan kontribusi sebagai data dukung penelitian tentang paleotsunami, sehingga dapat digunakan untuk memperkirakan kemungkinan kapan terjadinya tsunami di masa mendatang, sedangkan untuk metode pertanggalan ${ }^{210} \mathrm{~Pb}$ telah dilakukan penelitian mengenai laju sedimentasi serta penelitian tentang keberadaan alga berbahaya (harmful algal bloom, HAB) di dalam cuplikan sedimen yang sangat membahayakan lingkungan dan telah diteliti pada daerah-daerah tertentu. Dari hasil kajian menunjukkan bahwa pertanggalan radiokarbon yang didasarkan pencacahan ${ }^{14} \mathrm{C}$, pada masa yang akan datang para ahli pertanggalan radiokarbon kecenderungannya lebih memilih pertanggalan radiokarbon modern atau pertanggalan radiokarbon yang menggunakan alat spektrometer massa berbasis siklotron, disamping karena cuplikan yang dibutuhkan relatif jauh lebih kecil, juga hasil simpangan bakunya juga relatif lebih kecil.
\end{abstract}

Kata kunci: pertanggalan radiokarbon, geologi, arkeologi, paleotsunami

\begin{abstract}
THEROLEOF RADIOMEIRICDATING METHODINFIED DF THEARCHAEOLOGY AND GEOLOGY. The role of radiocarbon dating method in the field of geology and archaeology and ${ }^{210} \mathrm{~Pb}$ dating in the field of geology has been done. Radiocarbon dating method is a dating method with a maximum age restriction is 45,000 years old. This study is to review dating methods by using synthesis process that uses radioactive carbon $\left({ }^{14} \mathrm{C}\right)$ in the sample which is converted to benzene $\left({ }^{14} \mathrm{C}_{6} \mathrm{H}_{6}\right)$ and counted by liquid scintillation counter, while ${ }^{210} \mathrm{~Pb}$ dating method is that dating based on the measurement of ${ }^{210} \mathrm{~Pb}$ activity. This dating is special for sediments sample, with the maximum age of 150 years old. Some samples in the environment around the archaeological research and the geological site have been successfully carried out by radiocarbon dating analysis. Radiocarbon dating can also provide data as a contribution to support research on paleotsunami, so it can be used to estimate probability of the occurrence of tsunami in the future, while for ${ }^{210} \mathrm{~Pb}$ method dating has done research on the sedimentation rate as well as research on the existence of harmful algal (harmful algal bloom, HAB) sample in the sediments which is very dangerous to the environment and has been examined in certain areas. From the results of the study indicate that radiocarbon dating which based on the counting of the activity of ${ }^{14} \mathrm{C}$, in the future experts of radiocarbon dating is prefer to use of "modern" radiocarbon dating or radiocarbon dating by using mass spectrometry based on cyclotron method, because samples needed and standard deviation of the results relatively much smaller.
\end{abstract}

Keywords: radiocarbon dating, geology, archaeology, paleotsunami 


\section{PENDAHULUAN}

Dertanggalan atau dating (menentukan umur suatu cuplikan) secara radiometris adalah metode pertanggalan yang didasarkan pada pengukuran radioaktivitas suatu unsur. Radioaktivitas adalah kemampuan inti atom yang tak-stabil untuk memancarkan radiasi menjadi inti yang stabil. Materi yang mengandung inti tak-stabil yang memancarkan radiasi, disebut zat radioaktif. Besarnya radioaktivitas suatu unsur radioaktif (radionuklida) ditentukan oleh konstanta peluruhan $(\lambda)$, yang menyatakan laju peluruhan tiap detik, dan waktu paro $\left(t \frac{1}{2}\right)$. Kedua besaran tersebut bersifat khas untuk setiap radionuklida. Dengan mengukur nilai radioaktivitas pada saat tertentu, kemudian dibandingkan dengan radioaktivitas awal, maka akan dapat ditentukan nilai dari t (umur).

Ada beberapa macam pertanggalan radiometris yang telah dikenal( ${ }^{(1)}$, antara lain metode pertanggalan $\mathrm{U}-\mathrm{Pb}$, U-Th K-Ar (potassium argon dating), pertanggalan Rb-Sr, Sm-Nd, pertanggalan jejak belah (fission track dating), thermoluminescence, pertanggalan radiokarbon (radiocarbon dating), pertanggalan ${ }^{210} \mathrm{~Pb}$ dan lain-lain.

Metode pertanggalan radiokarbon mula-mula dikembangkan oleh para ilmuwan yang dipimpin oleh Profesor Willard F. Libby dari Universitas Chicago pada tahun 1952, beliau menerima Hadiah Nobel dalam bidang Ilmu Kimia pada tahun 1960 untuk penemuannya tersebut(2,3). Pada prinsipnya, metode pertanggalan radiokarbon adalah metode penentuan umur suatu cuplikan yang didasarkan pada pengukuran aktivitas ${ }^{14} \mathrm{C}$ (radiokarbon). Batas pengukuran pertanggalan radiokarbon adalah sampai dengan sekitar 45.000 tahun. Adapun macam cuplikan yang dapat ditentukan umurnya dengan metode pertanggalan radiokarbon adalah cuplikan lingkungan yang terkait dengan obyek penelitian yang berupa sisa habitasi yang berada di sekitar obyek penelitian seperti: arang, kayu, kerang, $\operatorname{tanah}^{(3)}$ (yang mengandung bahan organik), tulang dan lain-lain. Seperti diketahui bahwa pada saat ini terdapat sekitar 130 laboratorium pertanggalan radiokarbon(4) di seluruh dunia. Di Indonesia laboratorium pertanggalan radiokarbon ada di 3 instansi, yaitu di PTAPB-BATAN Yogyakarta, di PATIR-BATAN, Jakarta, dan di P3G, Bandung.

Pertanggalan ${ }^{210} \mathrm{~Pb}$ pertama kali diperkenalkan pada tahun 1963 oleh Golberg ${ }^{(5,6)}$ dan telah dikembangkan secara luas oleh Appleby dan Oldfield pada tahun 1979. Metode pertanggalan ini didasarkan pada proses alami yaitu terbentuknya ${ }^{210} \mathrm{~Pb}$ jatuhan, hasil peluruhan ${ }^{222} \mathrm{Rn}$ yang merupakan radionuklida yang dapat teradsorpsi kuat pada mineral/partikel tanah atau sedimen, sehingga dapat dijadikan sebagai perunut (tracer) untuk mempelajari pergerakan atau perpindahan tanah/sedimen.

Di lingkungan BATAN pertanggalan 210 Pb dikembangkan di PTAPB-BATAN Yogyakarta dan di PATIR-BATAN, Jakarta, serta di beberapa instansi terkait seperti LIPI, BPPT dan lain-lain. Di Asia, khususnya di Asia Tenggara metode ini dalam dekade terakhir telah dilakukan koordinasi dan kerjasama penelitian serta pelatihan yang diadakan oleh instansi tenaga nuklir negara anggota IAEA dan dimotori oleh Badan Tenaga Atom Internasional (IAEA).

Lingkup penelitian pertanggalan radiokarbon lebih ditekankan pada bidang arkeologi dan geologi, sedangkan pertanggalan ${ }^{210} \mathrm{~Pb}$ pada bidang geologi. Penerapan pertanggalan radiokarbon di bidang arkeologi antara lain penelitian tentang adanya komonitas manusia pada suatu daerah sekitar ribuan tahun yang lalu, data hasil pertanggalan radiokarbon beberapa situs Candi di Jawa menunjukkan kronologis pengaruh Hindu-Budha, sedangkan untuk bidang geologi telah diteliti tentang aliran awan panas yang terjadi pada sekitar ribuan tahun yang lalu, juga tentang kontroversi terjadinya proses erupsi Gunung Merapi pada masa lalu. Pertanggalan radiokarbon dapat juga memberikan kontribusi sebagai data dukung penelitian tentang paleotsunami, sehingga dapat digunakan untuk memperkirakan kemungkinan kapan terjadinya tsunami di masa mendatang. Untuk metode pertanggalan ${ }^{210} \mathrm{~Pb}$ di bidang geologi telah dilakukan penelitian mengenai laju sedimentasi di daerah pantai Jawa Barat, Jawa Tengah dan Jawa Timur dan lain-lain.

Diharapkan pada tahun-tahun mendatang di Indonesia dapat mengembangkan laboratorium pertanggalan radiokarbon yang lebih memadai, yaitu peralatan spetrometer massa yang berbasis siklotron dengan energi yang relatif rendah (orde puluhan $\mathrm{keV}$ ), ukuran alatnya tidak membutuhkan ruang yang besar, mudah pengoperasiannya, tetapi telah memenuhi harapan bagi para peneliti di bidang arkeologi maupun geologi, yaitu hanya membutuhkan berat cuplikan relatif kecil dan memberikan hasil simpangan baku yang lebih baik dibanding metode pertanggalan radiokarbon yang menggunakan alat pencacah kelip cair.

Untuk pertanggalan ${ }^{210} \mathrm{~Pb}$ pada masa kini maupun pada masa yang akan datang, perlu ditingkatkan penelitian tentang prakiraan periodisasi terjadinya peningkatan dengan cepat timbulnya alga berbahaya (harmful algal bloom, HAB) yang dapat menyebabkan lingkungan menjadi tercemar, banyak biota mati yang apabila dikonsumsi akan mengakibatkan fatal bagi kesehatan. 


\section{METODOLOGI}

Di alam terdapat 3 isotop karbon, yaitu ${ }^{12} \mathrm{C}(98,89 \%),{ }^{13} \mathrm{C}(1,11 \%)$ keduanya termasuk katagori isotop stabil, sedang yang ketiga adalah ${ }^{14} \mathrm{C}\left(1 \times 10^{-11} \%\right)^{(4)}$ termasuk isotop tidak stabil dan bersifat radioaktif. ${ }^{14} \mathrm{C}$ (radiokarbon) diproduksi di atmosfer paling atas yaitu dengan adanya reaksi antara radiasi kosmis dan nitrogen sehingga terbentuklah ${ }^{14} \mathrm{C}$. Radiokarbon ini dikombinasikan dengan oksigen yang kemudian membentuk karbon radioaktif dioksida yang dicampur secara seragam di atmosfer dan digabungkan ke dalam biosfer (mula-mula melalui fotosintesis) dan dipertukarkan dengan hidrosfer menghasilkan radiokarbon yang berkeseimbangan $\left({ }^{14} \mathrm{C}\right.$ yang meluruh akan seimbang dengan ${ }^{14} \mathrm{C}$ yang terbentuk). Ketika sebuah subsistem (pohon, kerang laut, dan lain lain) diisolasi dari sistem global (misalnya pohon ditebang, atau mati dan dikubur dalam tanah) kemudian tidak ada lagi radiokarbon yang ditambahkan padanya, maka aktivitas radiokarbon tersebut (sejumlah ${ }^{14} \mathrm{C}$ dalam subsistem atau cuplikan) mulai berkurang sesuai dengan hukum peluruhan radioaktif.

$$
A_{t}=A_{o} e^{-\lambda t}
$$

t dari rumus di atas adalah nilai umur dari cuplikan yang akan ditentukan, sudah barang tentu tidak sesederhana rumus tersebut. Rumus tersebut perlu dijabarkan lebih mendalam dan dikupas lebih jauh pada penjelasan berikutnya .

Di dalam penentuan umur suatu cuplikan pertanggalan radiokarbon perlu diperhatikan adanya beberapa asumsi-asumsi yang harus dipenuhi, antara lain[2]:

1. Produksi radiokarbon $\left({ }^{14} \mathrm{C}\right)$ di atmosfer konstan selama 50.000-100.000 tahun terakhir.

2. Pencampuran, pengambilan, dan pertukaran radiokarbon di dalam sistem atmosfer-biosfer-hidrosfer telah diseragamkan dan dipercepat dalam skala global untuk memberikan aktivitas awal yang sama untuk semua cuplikan.

3. Tingkat peluruhan radiokarbon adalah konstan, tidak ada karbon "muda" atau "tua" yang ditambahkan ke dalam cuplikan selama diisolasi dari keadaan keseimbangan global.

4. Tidak ada peluruhan isotop yang terjadi untuk mengubah perbandingan standar ${ }^{12} \mathrm{C}:{ }^{13} \mathrm{C}:{ }^{14} \mathrm{C}$ pada cuplikan.

Untuk memperoleh hasil pertanggalan yang akurat pada analisis pertanggalan radiokarbon, diperlukan koreksi fraksinasi isotop serta koreksi fluktuasi radiokarbon di masa lalu. Fluktuasi radiokarbon karena aktivitas manusia antara lain pembakaran bahan bakar (efek Suess ${ }^{(7)}$ ) dan pengujian senjata nuklir yang menyebabkan kandungan ${ }^{14} \mathrm{C}$ di atmosfer bumi pada tahun 1972 menjadi sekitar 4 kali dibanding 1962 . Terjadi perubahan kandungan ${ }^{14} \mathrm{C}$ sebesar $2 \%$ pada tahun $1500-1700{ }^{(8)}$ dibanding pada abad ke 19 (efek de Vries).

Salah satu sebab bervariasinya kandungan radiokarbon dalam cuplikan adalah bahwa isotop karbon mengalami fraksinasi karena reaksi fisika maupun kimia yang terjadi di alam, sebagai hasilnya kelimpahan isotop stabil $\left({ }^{12} \mathrm{C}\right.$ dan ${ }^{13} \mathrm{C}$ ) yang yang masuk dalam tumbuhan lewat fotosintesis berbeda dengan yang terdapat dalam $\mathrm{CO}_{2}$ dalam udara. Tumbuhan biasanya kaya akan ${ }^{12} \mathrm{C}$ dan kekurangan ${ }^{13} \mathrm{C}$ dan ${ }^{14} \mathrm{C}$. Aktivitas ${ }^{14} \mathrm{C}$ dalam jaringan tumbuhan berbeda dengan yang terdapat dalam kalsium karbonat yang terendapkan secara biologis. Dengan dilakukannya koreksi fraksinasi isotop sedemikian sehingga pengaruh berubah-ubahnya laju produksi ${ }^{14} \mathrm{C}$ dapat dihilangkan. Adapun koreksi akibat adanya fraksinasi isotop $\left(\mathrm{d}^{13} \mathrm{C}\right)$ dirumuskan seperti tersebut di bawah ini[2] :

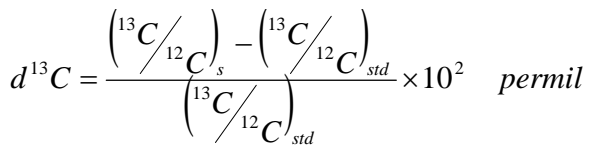

Pada penentuan umur pertanggalan radiokarbon diperlukan suatu referensi standar untuk kalibrasi dan dapat menjamin keseragaman dalam analisis. Dengan demikian hasil analisis pertanggalan radiokarbon suatu laboratorium tertentu dapat memberikan dasar umum untuk memperbandingkan pertanggalan-pertanggalan radiokarbon yang dihasilkan oleh berbagai laboratorium. Telah disepakati oleh para pakar radiokarbon bahwa sebagai standar referensi dalam pertanggalan radiokarbon digunakan asam oksalat yang diproduksi oleh Biro Standar Nasional Amerika Serikat (U.S. National Bureau of Standards). Standar aktivitas ${ }^{14} \mathrm{C}$ didefinisikan sebagai $95 \%$ dari aktivitas ${ }^{14} \mathrm{C}$ dalam Standar Asam Oksalat NBS(4). Berat cuplikan yang dipersyaratkan adalah 5 sampai 40 gram (tergantung cuplikannya). Bahkan(9) berat cuplikan hingga mencapai berat 180-2000 gram (untuk cuplikan tulang), hal ini untuk memperoleh ketepatan yang tinggi, karena berat cuplikan yang lebih kecil dari yang dipersyaratkan dapat mempengaruhi hasil pertanggalan radiokarbon, bahkan setelah dianalisis nilai 
penyimpangannya sangat besar. Satuan hasil pertanggalan yang telah disepakati para ahli pertanggalan radiokarbon adalah "before present" $(B P)^{(9)}$ (sebelum "saat ini"), sedangkan untuk saat ini diambil tahun 1950. Untuk memperoleh hasil pertanggalan dengan konversi satuan Sebelum Masehi (SM) atau Before Christ (BC) dan Sesudah Masehi (M) atau AD, maka hasil pertanggalan dengan satuan BP tersebut dikurangi 1950, bila hasilnya positif maka satuannya adalah SM , sedangkan bila hasilnya negatif maka satuannya adalah $\mathrm{M}$.

Pertanggalan radiokarbon di PTAPB adalah pertanggalan yang didasarkan pada pengukuran radioaktivitas beta dari ${ }^{14} \mathrm{C}$ melalui beberapa langkah, yang pertama adalah perlakuan awal berupa pencucian cuplikan, setelah itu dilanjutkan dengan proses pembakaran cuplikan (direaksikan dengan $\mathrm{O}_{2}$ ) $^{(2)}$, terbentuklah $\mathrm{CO}_{2}$. Sebagian $\mathrm{CO}_{2}$ yang terbentuk diambil, untuk kemudian dianalisis nilai ${ }^{13} \mathrm{C}$ menggunakan alat spektrometer massa, untuk koreksi hasil pertanggalan. Sebagian besar $\mathrm{CO}_{2}$ yang terbentuk tersebut di atas diproses lanjut sehingga terbentuk benzena $\left(\mathrm{C}_{6} \mathrm{H}_{6}\right)$, menggunakan alat benzene synthesizer. Benzena $\left(\mathrm{C}_{6} \mathrm{H}_{6}\right)$ hasil sintesis dari cuplikan dan standar (NBS 4990C), dan larutan "benzena mati" (sebagai latar), ketiga-tiganya ditambah sintilator cair, kemudian dicacah menggunakan alat pencacah kelip cair (liquid scintillation counter). Dengan membandingkan aktivitas jenis $14 \mathrm{C}$ dari cuplikan dengan standar dan koreksi $\mathrm{d}^{13} \mathrm{C}$ maka akan dapat dihitung pertanggalan (umur) cuplikan ${ }^{(2-4)}$ dengan rumus yang merupakan hasil penjabaran rumus ${ }^{(1)}$ :

$$
t=8033 \ln \frac{S_{s t d}}{S_{\text {smp }}}+8033 \ln \frac{1}{1-\frac{2\left(d^{13} C+25\right)}{1000}}
$$

$\begin{array}{ll}S_{\text {std }} & =\text { Aktivitas spesifik asam oksalat standard, } \\ S_{\text {smp }} & =\text { Aktivitas spesifik dari cuplikan. } \\ t & =\text { umur dalam BP ( before present, sebelum saat ini) } \\ d^{13} \mathrm{C} & =\text { harga delta }{ }^{13} \mathrm{C} \text { (koreksi fraksinasi isotop) }\end{array}$

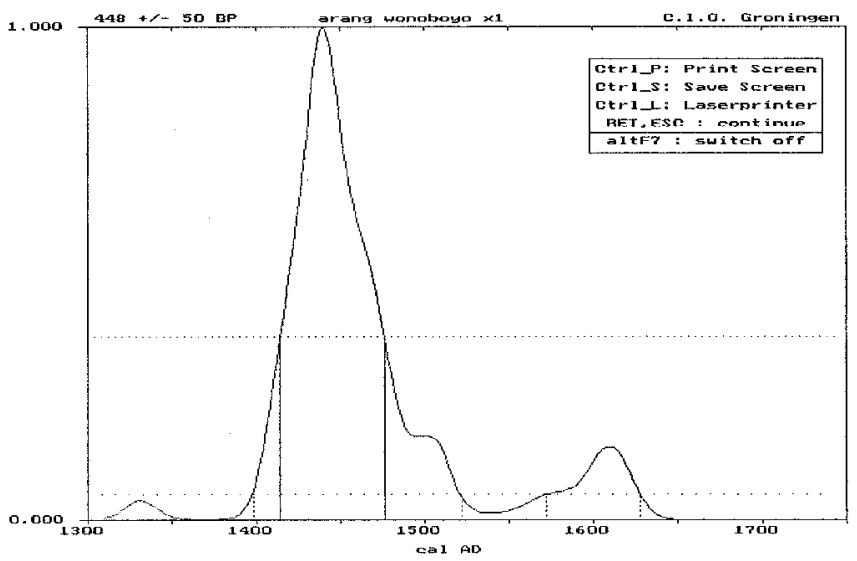

Gambar 1. Grafik dari cuplikan arang Wonoboyo dengan koreksi tree-ring (lingkaran pohon).

Setelah dilakukan koreksi fraksinasi isotop, perlu dikoreksi lagi dengan koreksi lingkaran pohon (tree ring correction) sedemikian sehingga nilai umur yang dianalisis dapat memenuhi apa yang dipersyaratkan oleh para pakar. Sebagai gambaran untuk koreksi lingkaran pohon dapat dilihat data perhitungan umur cuplikan arang dari situs Wonoboyo yang nilai umurnya setelah dikoreksi dengan nilai $\mathrm{d}^{13} \mathrm{C}$ (rumus nomer 3 ) adalah 447,67 BP, maka bila data umur tersebut dimasukkan dalam program tree ring correction ${ }^{(10)}$ maka akan diperoleh gambar seperti yang telah terlihat pada Gambar 1.

Dari gambar tersebut terlihat bahwa bila yang digunakan nilai umur pada tingkat kepercayaan $68,3 \%$, maka nilai umur cuplikan tersebut adalah 1414-1476 M, sedang pada tingkat kepercayaan 95,4 \% berkisar 1398-1628 M. Bila tidak dilakukan koreksi, nilai umurnya adalah 1502,33 $\pm 50,16 \mathrm{M}$. Dengan adanya koreksi-koreksi ini diharapkan hasil pertanggalan radiokarbon menjadi lebih akurat dan dapat dipertanggung jawabkan. Pertanggalan radiokarbon yang menggunakan alat pencacah kelip cair tersebut, para pakar menyebutkannya sebagai metode 
pertanggalan "konvensional". Untuk memperoleh hasil yang optimal dalam analisis pertanggalan radiokarbon perlu dikembangkan metode pertanggalan "modern", yaitu metode pertanggalan yang menggunakan alat spektrometer massa berbasis akselerator yaitu accelerator mass spectrometry (spektromassa akselerator). Adapun metodologi spektromassa akselerator adalah sebagai berikut(11):

Cuplikan ditampung dalam cesium beam sputter source yang mampu menampung hingga 40 cuplikan. Untuk pengukuran ${ }^{14} \mathrm{C}$, cuplikan harus dalam keadaan karbon padat yang dicampur dengan suatu katalisator tertentu sedemikian sehingga terjadi proses grafitisasi. Ion negatif karbon C-, diekstrakkan dari sumber, dipercepat hingga voltase tertentu $(\mathrm{keV})$ dan dipilih berdasar tenaganya dengan analiser elektrostatik. Kemudian akan melewati magnit injektor yang resolusinya sangat tinggi untuk menganalisiis massanya. Tabung magnet hampa yang dikungkung listrik dan dapat diukur dalam orde milisekon kemudian diberi tegangan tertentu sedemikian sehingga isotop karbon dengan massa berbeda $\left({ }^{12} \mathrm{C},{ }^{13} \mathrm{C}\right.$ dan $\left.{ }^{14} \mathrm{C}\right)$ dapat melewatinya, energi yang dihasilkan memiliki kekenyalan magnetik yang sama. Ini berarti ketiga isotop karbon dapat dimasukkan dalam waktu cepat melalui sistem akselerator, yang dapat meningkatkan ketepatan pengukuran perbandingan isotop dengan mencuplik sebagian kecil namun tidak mengganggu kestabilan sistem. Sangkar Faraday yang telah diset sedemikian sehingga dapat bergerak memonitor arus ion dari isotop ${ }^{12} \mathrm{C},{ }^{13} \mathrm{C}$ dan ${ }^{14} \mathrm{C}$. Ketiga isotop tersebut dilewatkan pada magnetic mass analyzer, kemudian dicacah dengan detektor gas yang dihubungkan dengan sistem komputasi sedemikian sehingga dapat diperoleh nilai umur cuplikan.

Adapun penyiapan target akselerator adalah sebagai berikut :

1. Cuplikan dibakar pada suhu $900^{\circ} \mathrm{C}$ sambil dialiri gas $\mathrm{O}_{2}$ sehingga karbon $(\mathrm{C})+\mathrm{O}_{2}$ menjadi $\mathrm{CO}_{2}$

2. $\mathrm{CO}_{2}$ tersebut direduksi dengan cara mereaksikannya gas $\mathrm{CO}_{2}$ tersebut dengan $\mathrm{Mg}$ (panas) menjadi $\mathrm{C}$ dan $\mathrm{MgO}$

3. C yang terjadi ditambah serbuk Fe dengan perbandingan 1:15

4. Campuran yang terjadi dileburkan dalam suasana argon (Ar) sehingga terbentuk pelet $\mathrm{FeC}$

Pelet FeC ini akan membentuk target akselerator dan dipasang pada penyangga target dan dimasukkan dalam sumber ion. Akan tetapi peralatan ini membutuhkan tempat yang cukup besar dan beaya pembelian alat serta pemasangan yang relatif cukup mahal, sehingga dibutuhkan anggaran yang cukup besar. Untuk itu perlu dikembangkan metode lain yang lebih dapat dijangkau, salah satunya adalah spektrometer massa yang bebasis siklotron. Pada metode ini cuplikan yang dibutuhkan relatif jauh lebih sedikit, penyimpangan hasil analisisnya juga relatif lebih kecil. Dibandingkan alat spektrometer massa akselerator dengan energi 10 - $30 \mathrm{MeV}$, maka spektrometer massa berbasis siklotron hanya membutuhkan energi kurang dari $100 \mathrm{keV}$, beaya yang dibutuhkan relatif lebih murah $(\$ 100.000)$, dan ukuran alatnya tidak membutuhkan ruang yang besar. Alat ini telah dikembangkan oleh para pakar antara lain R.A. Muller dan kawan-kawan pada tahun 1977.(12-4)

Pertanggalan ${ }^{210} \mathrm{~Pb}$ adalah metode pertanggalan yang didasarkan pada pengukuran aktivitas ${ }^{210} \mathrm{~Pb}$. Pertanggalan(6) ini khusus diperuntukkan untuk cuplikan sedimen, dan batasan umurnya maksimum adalah 150 tahun. Metode ini telah berhasil diaplikasikan pada danau muara dan lingkungan sekitar pantai dan diperoleh hasil laju sedimentasi berkisar dari satuan milimeter hingga sentimeter per tahun. Metode pertanggalan ${ }^{210} \mathrm{~Pb}$ banyak digunakan untuk sedimen-sedimen muara dan danau, karena laju peluruhan dapat diketahui dari ${ }^{210} \mathrm{~Pb}$ yang terkonsentrasi dalam lapisan sedimen. ${ }^{210} \mathrm{~Pb}$ yang berasal dari jatuhan sebagai anak luruh ${ }^{222} \mathrm{Rn}$ biasa disebut ${ }^{210} \mathrm{~Pb}$ excess. ${ }^{(15)}$ Jatuhan ${ }^{210} \mathrm{~Pb}$ pada suatu tempat relatif stabil, karena sumber dari ${ }^{222} \mathrm{Rn}$ adalah batuan/tanah sekitar. Karena sifat teradsorpsi kuat pada partikel tanah/sedimen, ${ }^{210} \mathrm{~Pb}$ excess dapat digunakan untuk mengetahui redistribusi tanah yaitu pola-pola laju erosi/sedimentasi dari suatu tempat. ${ }^{210} \mathrm{~Pb}$ excess yang jatuh di permukaan laut atau suatu danau/reservoar akan terdeposit bersamaan dengan pembentukan lapisan sedimen. Dengan pengambilan sedimen undisturbed, dapat diketahui profil ${ }^{210} \mathrm{~Pb}$ excessnya, dan dapat digunakan untuk menentukan umur tiap lapisan sedimen sekaligus untuk menentukan kronologi terjadinya pencemaran polutan baik organik maupun anorganik.

Pada saat preparasi cuplikan sedimen tersebut, cuplikan harus diisolasi pada wadah tertentu sedemikian dibiarkan selama sekitar 30 hari[15] hingga telah terjadi kesetimbangan sekular (secular equilibrium), setelah itu baru dapat dianalisis. ${ }^{210} \mathrm{~Pb}$ adalah radioisotop alam dari deret $238 \mathrm{U}$. ( $\mathrm{t} 1 / 2=22,25$ tahun). Seperti diketahui bahwa sumber ${ }^{210} \mathrm{~Pb}$ dapat berasal dari lapisan tanah maupun dari atmosfer. Sumber yang dari tanah berasal dari ${ }^{226} \mathrm{Ra}$ yang merupakan anak luruh ${ }^{238} \mathrm{U}$. Hasil peluruhan ${ }^{226} \mathrm{Ra}$ adalah ${ }^{210} \mathrm{~Pb}$ (supported ${ }^{210} \mathrm{~Pb}$ ) yang membentuk kesetimbangan dengan ${ }^{210} \mathrm{Po}$, sedangkan yang datang dari atmosfer adalah berasal ${ }^{222} \mathrm{Rn}$ yang menguap ke udara, di udara ${ }^{222} \mathrm{Rn}$ membentuk ${ }^{210} \mathrm{~Pb}$ (excess ${ }^{210} \mathrm{~Pb}$ ) setimbang dengan ${ }^{210} \mathrm{Po}$ turun ke air, bersama-sama dengan partikel dalam air yang kemudian mengendap. Jadi yang disebut aktivitas excess ${ }^{210} \mathrm{~Pb}=$ aktivitas ${ }^{210} \mathrm{~Pb}$ total - aktivitas supported 
${ }^{210} \mathrm{~Pb}$. Pertanggalan ${ }^{210} \mathrm{~Pb}$ menggunakan 3 macam satuan, yang pertama untuk menghitung estimasi umur cuplikan sedimen satuannya adalah tahun, yang kedua untuk menghitung kecepatan sedimentasi satuannya tahun/cm, yang ketiga untuk menghitung fluks massa sedimentasi satuannya adalah $\mathrm{kg} \mathrm{m}^{-2}$ tahun ${ }^{-1}$.

Pertanggalan ${ }^{210} \mathrm{~Pb}$ tersebut merupakan salah satu data dukung yang dapat membantu penelitian tentang prakiraan periodisasi terjadinya peningkatan dengan cepat dalam waktu yang singkat suatu cyst atau alga berbahaya ${ }^{(15,16)}$ yang sangat membahayakan lingkungan.

Alga adalah organisme eukariotik bersel tunggal dan mikroskopik yang sebagian hidup di laut. Hampir sebagian besar spesies alga atau fitoplankton tidak berbahaya dan berfungsi sebagai penghasil energi pada rantai makanan di laut. Sejumlah spesies alga manghasilkan toksin yang dapat ditransferkan melalui jaringan makanan di mana mereka dapat mempengaruhi dan bahkan membunuh organisme yang lebih tinggi tingkatannya, seperti zooplankton, kerang-kerangan, ikan, burung, mamalia laut, dan bahkan manusia yang mengkonsumsinya baik secara langsung maupun tidak langsung. Sekarang para peneliti lebih memakai istilah harmful algal blooms (HAB) untuk menggambarkan fenomena yang berkaitan dengan toksin maupun dampak negatif dari alga.

Salah satu akibat dari peningkatan bahan organik dari limbah di sebuah perairan pesisir tertentu, adalah terbentuknya cyst suatu jenis fitoplankton yang berbahaya yang kemudian bloom (meningkat dalam waktu yang singkat), yaitu fenomena peledakan populasi fitoplankton berbahaya di perairan secara cepat dan dalam jumlah yang sangat besar yang disebabkan oleh tersedianya unsur hara dalam jumlah besar. Adanya mobilitas kapal yang dari dan ke daerah pantai tertentu sangat mempengaruhi keberadaan fitoplankton-fitoplankton di lingkungan sekitar pantai tersebut.

Pada saat tertentu unsur hara serta faktor fisik dan kimia perairan antara lain salinitas, suhu, COD, pH dan lain-lain mengalami perubahan sedemikian, maka fitoplankton tersebut akan melindungi diri dengan membentuk cangkang sedemikian sehingga membentuk cyst yang akan ikut mengendap bersama mengendapnya sedimen. Apabila pada suatu saat unsur hara serta faktor fisik dan kimia perairan terpenuhi kondisi sedemikian, maka cyst tadi akan keluar melepaskan cangkangnya dan melakukan proses pembiakan secara cepat sedemikian dan meledaklah populasi fitoplankton ini sehingga akan mempengaruhi ekosistem, karena ada beberapa jenis fitoplankton tersebut adalah fitoplankton yang sangat beracun ${ }^{(16)}$.

Di hampir semua negara maju, pemantauan perairan pesisir yang terkait dengan laju sedimentasi serta bloom fitoplankton merupakan kegiatan rutin. Selain sebagai fungsi dari sebuah sistem peringatan dini, monitoring rutin, perawatan juga merupakan eksplorasi berkesinambungan untuk terus mencari jawaban tentang misteri ekosistem pesisir. Program pemantauan sedimen dan keberadaan cyst ini di Indonesia termasuk salah satu yang dikoordinasi oleh IAEA untuk kawasan Asia Pasifik dan sekitarnya.

\section{PENERAPAN PERTANGGALAN RADIOKARBON DAN PERTANGGALAN 210PB DI PTAPB-BATAN DAN DI INSTANSI TERKAIT}

Adapun cuplikan lingkungan yang telah dilakukan analisis dengan metode pertanggalan radiokarbon baik di laboratorium .pertanggalan PTAPB maupun laboratorium di instansi lain antara lain:

1. Cuplikan organik akibat aktivitas vulkanik atau yang terendapkan bersama sedimen (tanah) pada beberapa lokasi di daerah Watuadeg Kalasan, Sleman Yogyakarta.(17) Di lokasi ini tersingkap endapan vulkanik yang beralaskan pasir tufa yang mengandung arang. Pertanggalan dilakukan pada paleosoil serta pada pasir tufa yang berarang, dengan tujuan untuk mengetahui kapan terbentuknya paleosoil serta kapan endapan awan panas terjadi. Cuplikan Pasir Tufa Watuadeg Umur Absolut 3709,74 \pm 124,45 SM, Cuplikan Paleosoil Watuadeg Umur Absolut 3780,16 \pm 120,42 SM. Hal itu menunjukkan bahwa awan panas dari efek vulkanik Gunung Merapi telah mengalir pada daerah tersebut (sekitar $30 \mathrm{~km}$ ) pada sekitar 4000 tahun yang lalu. Sedang pada letusan pada era tahun 2000 baru-baru ini aliran awan panas hanya mengalir sejauh $10 \mathrm{~km}$.

2. Cuplikan kayu (fosil tanaman) dari daerah Borobudur(18) dan sekitarnya juga telah dilakukan analisis. Hasil penelitian menunjukkan bahwa daerah di sekitar Bukit Borobudur pernah terbentuk lingkungan danau. Dalam hal ini pertanggalan radiokarbon berperan untuk mengetahui kapan terjadinya perubahan dari danau menjadi dataran. Hasil analisis pertanggalan radiokarbon ${ }^{14} \mathrm{C}$, berdasarkan cuplikan yang diambil dari fosil tanaman (kayu) terkandung di dalam sedimen danau, maupun cuplikan fosil tanaman (kayu) yang terkandung di dalam sedimen vulkanik penutup endapan danau, dapat diketahui bahwa lingkungan danau di cekungan Borobudur, masih berlangsung pada tahun $1271 \mathrm{M}$, berakhirnya lingkungan danau pada tahun $1288 \mathrm{M}$. Berdasarkan analisis pertanggalan radiokarbon tersebut dapat disimpulkan bahwa lingkungan Danau Borobudur masih berlangsung 
pada tahun 1271 Masehi. Ini menunjukkan hipotesis van Bemmellen (1952)(18) tentang terbentuknya lingkungan danau Borobudur sebagai akibat letusan kuat Gunung Merapi pada tahun 1006 Masehi, menjadi sangat lemah.

3. Penelitian pertanggalan radiokarbon yang menyelidiki tentang paleotsunami yang terjadi di daerah Pangandaran yang dilakukan oleh Dr Eko Yulianto, Ketua Tim Peneliti Geoteknologi LIP|(19). Dalam penelitian tersebut dijelaskan bahwa suatu lapisan sedimen pada kedalaman tertentu pada peristiwa tsunami pada masa lalu (paleotsunami) atau proses geologis lainnya dapat digunakan untuk memperkirakan kemungkinan kapan terjadinya tsunami di masa mendatang. Penelitian didahului dengan mengetahui umur sedimen dengan pertanggalan radiokarbon kemudian diikuti penelitian tentang analisis pollen dan analisis isotop stabil serta penelitian geologi lainya, kemudian dari data-data tersebut dibuat model sedemikian sehingga dapat diperkirakan periodisasinya terjadinya tsunami tersebut. Sebagai contoh adalah telah ditemukannya jejak tsunami yang berupa sedimen dan material dari laut pada kedalaman tertentu ditemukan di Desa Cikembulan di sebelah barat Pangandaran pada kedalaman sekitar 2 meter. Lapisan ini terdiri dari pasir besi yang berasosiasi dengan lempung. Hal ini menunjukkan lokasi ini pernah mengalami pengangkatan dan tsunami. Material lempung menunjukkan daerah tersebut dulunya, ratusan hingga ribuan tahun lalu, berupa laguna (danau di tepi pantai) yang mengalami pengangkatan akibat proses geologis. Untuk mengetahui tahun kejadian tsunami, cuplikan sedimen yang ditemukan tersebut ditentukan umurnya dengan pertanggalan radiokarbon. Dengan mengetahui kejadian tsunami masa lalu, periode pengulangan kegempaan yang menimbulkan tsunami akan dapat diperkirakan. Dengan demikian prediksi akan terjadinya tsunami di masa datang dapat diketahui.

4. Penelitian pertanggalan radiokarbon yang menyelidiki tentang iklim global telah terjadi pada tahun sekitar 2300 SM di daerah Turki, Palestina, Syria dan Irak, kota-kota Mesir Tua, kawasan Jazirah Arabia dan Mesopotamia. Gejala yang sama ternyata terjadi juga di benua Amerika, Madagaskar, India dan Australia Barat. Para peneliti ternama menemukan adanya jejak-jejak perubahan iklim, yang menyebabkan kekeringan dahsyat yang berlangsung selama 300 tahun (20).

5. Cuplikan arang dari lingkungan di sekitar Candi Gondosuli, Pringapus(21,23) dan Gedongsongo(22,23) (Jawa Tengah), telah dilakukan pertanggalan mutlak. Hasil pertanggalan mutlak (pertanggalan radiokarbon) menunjukkan bahwa budaya Hindu-Budha ternyata berlanjut minimal sampai abad ke-15. Untuk cuplikan arang pada berbagai Candi di Jawa Timur antara lain Candi Jabung(24), hasil pertanggalan mutlak 1281-1624 M, hasil pertanggalan relatif $1354 \mathrm{M}$. Candi Kidal(25) menunjukkan 1022-1230 M, hasil pertanggalan relatif $1248 \mathrm{M}$. Hasil pertanggalan mutlak Candi Tegowangi(26) 1267-1460 M, hasil pertanggalan relatif sekitar $1400 \mathrm{M}$, Candi Sumberawan(26), hasil pertanggalan mutlak 1428-1692 M, sedangkan hasil pertanggalan relatif sekitar $1359 \mathrm{M}$, Candi Brahu(27) Timur. menunjukkan abad ke 14, hal ini masih relefan dengan data sejarah yang menyebutkan bahwa era Majapahit berkisar dari abad ke 10 sampai abad ke 15. Dari data tersebut menunjukkan bahwa hasil pertanggalan relatif masih "dalam rentang ukur" pertanggalan absolut. Secara garis besar kelompok candi Jawa Tengah dengan kelompok Jawa Timur pengaruh budaya Hindu-Budha di Jawa Tengah abad ke-8 s/d ke-9 lebih tua dibanding dengan Jawa Timur, yaitu abad ke-13 s/d ke-15.

6. Pertanggalan mutlak dan relatif telah dilakukan di daerah Wonoboyo, Klaten Surakarta. Di situs Wonoboyo (10) tersebut telah ditemukan temuan arkeologi yang fenomenal. Di situs tersebut dijumpai dua kelompok temuan arkeologik. Temuan pertama adalah tinggalan arkeologik berupa sisa pemukiman kuno yang secara umum berada di bawah Dusun Plosokuning sekarang, sedangkan temuan kedua adanya artefak emas seberat $32 \mathrm{~kg}$ di tepi sungai yang berjarak sekitar 90 meter di sebelah timur sisa pemukiman kuno tersebut. Temuan artefak emas dalam jumlah yang relatif besar itu, diperkirakan ada hubungannya dengan sisa pemukiman kuno seperti yang telah disebutkan di atas, sehingga masyarakat menganggap situs tersebut adalah bekas ibukota kerajaan. Namun dari temuan $32 \mathrm{~kg}$ artefak emas Situs Wonoboyo secara obyektif tidak ada hubungannya dengan sisa pemukiman kuno. Dengan kata lain anggapan bahwa pemukiman kuno tersebut sebagai bekas pusat kekuasaan politik atau lokasi ibukota kerajaan perlu diragukan. Untuk meyakinkan keragu-raguan dari pertanggalan relatif tersebut, perlu dilakukan pertanggalan mutlak terhadap temuan cuplikan arang dan penelitian lain yang terkait yang diharapkan dapat memperkuat argumentasi yaitu dengan analisis tapak daun. Dengan melakukan penggabungan data yang diperoleh dari penelitian tersebut akan dapat diperoleh gambaran mengenai beberapa aspek yang berhubungan dengan situs Wonoboyo, sehingga dapat untuk mengetahui keadaan lingkungan dan umur (pertanggalan) situs. Dua buah cuplikan arang telah diperoleh pada kedalaman yang sama tetapi dibawa oleh peneliti yang berbeda. Yang satu dari Fak.Sastra UGM sedangkan yang satu lagi dari Balai Arkeologi Yogyakarta. Setelah dianalisis dengan pertanggalan radiokarbon, hasilnya tidak jauh berbeda. Dari data jejak daun dan dibantu dengan temuan lain yang bersifat artefaktual maka dapat membantu 
dan memperjelas untuk interpretasi situs ini, sehingga dapat disimpulkan areal situs Wonoboyo lebih cenderung menguatkan ke arah status situs pemukiman, bukan situs suatu lokasi keraton atau pusat pemerintahan kerajaan Mataram kuna. Dari hasil pertanggalan mutlak menunjukkan situs tersebut adalah pada era abad XIV-XVI. Sedangkan analisis dari jejak daun menunjukkan Situs Wonoboyo bukanlah tempat keraton (kerajaan). Maka dapat disimpulkan bahwa Situs Wonoboyo hanyalah tempat menyimpan benda bersejarah tersebut yang umurnya sekitar abad ke IX-X yang disimpan pada abad XIV-XVI.

7. Pertanggalan radiokarbon di daerah Song Keplek(28) (Gua di daerah Gunung Sewu) hasil pertanggalan menunjukkan cuplikan arang $=6742,33 \pm 122,07$ BP atau 4792,33 $\pm 122,07$ S M (Sebelum Masehi), sedangkan dari tinjauan pustaka diperkirakan umur relatif dari daerah penelitian adalah sekitar 5000 SM. Sehingga bila dibandingkan antara pertanggalan relatif dengan data analisis pertanggalan absolut terlihat tidak ada perbedaan yang signifikan. Jadi dapat diperkirakan bahwa pada 5000 tahun sebelum Masehi sudah ada komunitas manusia di daerah penelitian yaitu daerah Song Keplek (Gua di daerah Gunung Sewu), Jawa Tengah.

8. Penelitian pertanggalan radiokarbon(29) tentang arkeologi yang didanai National Geographic Society Mission Programme, Lee Berger dan rekan-rekannya dari University of the Witwatersrand, Rutgers University dan Duke University, memberikan gambaran tentang temuan fosil manusia kerdil dari pulau Palau di Mikronesia. Orang kerdil ini mendiami pulau itu berdasarkan analisis pertanggalan radiokarbon antara 1400-3000 tahun silam. Penelitian tersebut memperdebatkan tentang apakah fosil itu merupakan manusia modern (Homo sapiens) dengan ukuran yang mengecil, karena suatu hal, atau apakah mereka merupakan spesies baru Homo floresiensis. Untuk itu para peneliti tersebut akan melanjutkan penelitian sehingga akan terjawab perdebatan tersebut.

Hasil penelitian pertanggalan ${ }^{210} \mathrm{~Pb}$ di PTAPB maupun di instansi di lingkungan BATAN antara lain:

1. Penelitian Estimasi Kecepatan Pengendapan Di Pantai Cirebon ${ }^{(30)}$ menunjukkan bahwa fluks massa pengendapan tercepat adalah pada kedalaman $2-4 \mathrm{~cm}$ sebesar $1,49 \mathrm{~kg} / \mathrm{m}^{2}$.tahun terendah pada kedalaman 8 $-10 \mathrm{~cm}$ sebesar $0,43 \mathrm{~kg} / \mathrm{m}^{2}$.tahun. Dari analisis cyst pada sedimen dipantai Cirebon belum diketemukan adanya cyst algae berbahaya (harmful algal bloom, $H A B)^{(31)}$

2. Penelitian Estimasi Kecepatan Pengendapan di Pantai Ciamis Selatan ${ }^{(32)}$ menunjukkan bahwa kecepatan sedimentasi berkisar antara 0,07-1,24 dan 1,36-37,50 cm/tahun, sedangkan fluks massa pengendapan berkisar antara 0,49-7,42 kg/m².tahun. sampai dengan $8,42-422,58 \mathrm{~kg} / \mathrm{m}^{2}$.tahun. Dari analisis cyst pada sedimen di pantai Ciamis Selatan belum diketemukan adanya cyst algae berbahaya (HAB) ${ }^{(33)}$

3. Penelitian Laju Sedimentasi dan Akumulasi Massa Sedimen di Pantai Surabaya ${ }^{(34)}$, kecepatan sedimentasi pada 2 lokasi berkisar antara $0,046 \mathrm{~cm} /$ tahun sampai $0,858 \mathrm{~cm} / \operatorname{tahun}$ dan $0,084 \mathrm{~cm} /$ tahun sampai $0,498 \mathrm{~cm} /$ tahun sedangkan fluks massa pengendapan berkisar antara $28,45 \mathrm{~kg} / \mathrm{m}^{2}$ tahun sampai $316,36 \mathrm{~kg} / \mathrm{m}^{2}$ tahun dan antara $16,062 \mathrm{~kg} / \mathrm{m}^{2}$ tahun sampai $1,196 \mathrm{~kg} / \mathrm{m}^{2}$ tahun.

4. Penelitian Laju Sedimentasi dan Akumulasi Massa Sedimen di Situ Pamulang(35) menunjukkan bahwa fluks massa pengendapan stabil yang signifikan; yaitu antara tahun 1928 sampai tahun 1964, antara tahun 1964 sampai tahun 1974 dan antara tahun 1974 sampai tahun 1986, dari tahun 1986 sampai 1995 mempunyai nilai yang relatif konstan.

5. Penelitian Studi Geokronologi Sedimen Di Perairan Pantai Lokasi Tapak PLTN Ujung Lemahabang, Semenanjung Muria(36), menunjukkan bahwa pada kedalaman coring sediment antara $19-28 \mathrm{~cm}$ mempunyai umur 96 - 128 tahun. Analisis cyst pada sedimen di pantai Semenanjung Muria terdapat beberapa cyst algal berbahaya $(\mathrm{HAB})^{(37)}$ yaitu di daerah Bayuran, Bondo, Bringin.

6. Penelitian tentang adanya red tide di Teluk Jakarta(38). Seperti diketahui bahwa pada tahun 1979 telah terjadi peledakan populasi fitoplankton (cyst algal) beracun dan berbahaya (HAB) secara cepat dan dalam jumlah yang sangat besar, sehingga warna air laut menjadi berubah yang dikenal dengan red tide yang menyebabkan kematian biota serta makhluk di sekitarnya. Hal yang sama terjadi di New England pada tahun 1972, yaitu ribuan ton kerang-kerangan tidak bisa dimanfaatkan, sedangkan ikan-ikan bergelimpangan tidak terhitung jumlahnya. Hal itu terjadi karena serangan dari cyst algal beracun. Di Indonesia jenis fitoplankton beracun tersebut disinyalir juga ditemukan di Teluk Kao (Maluku Utara), Teluk Piru dan Teluk Elpaputih (Maluku Tengah), dan perairan Sorong, perairan Manokwari, laut bagian utara Papua, serta teluk Cendrawasih (Papua).

PROSPEK PERTANGGALAN RADIOKARBON DAN PERTANGGALAN 210PB DI MASA YANG AKAN DATANG 
Untuk memperoleh hasil yang optimal dalam analisis pertanggalan radiokarbon dapat dikembangkan alat spektrometer massa berbasis siklotron, yang energinya hanya sekitar $40-70 \mathrm{keV}\left({ }^{(12-14)}\right.$, cuplikan yang dibutuhkan relatif jauh lebih sedikit, penyimpangan hasil analisisnya juga relatif lebih kecil. Di PTAPB sedang dilakukan studi pendahaluan tentang alat spektrometer massa berbasis siklotron ini, tetapi terkendala masalah sumber ion.

Selain dapat mendeteksi ${ }^{14} \mathrm{C}$, dengan pengembangan tertentu pada waktu mendatang peralatan ini dapat dimanfaatkan untuk analisis kandungan isotop ${ }^{129}$ (kedokteran nuklir), ${ }^{3 \mathrm{H}}$ (hidrologi), ${ }^{26} \mathrm{Al}$ dan ${ }^{10} \mathrm{Be}$ (geologi). Pada saat ini laboratorium pertanggalan radiokarbon di Indonesia masih dalam katagori pertanggalan "konvensional". Diharapkan pada tahun-tahun mendatang dengan dijalinnya kerjasama antar instansi terkait, Indonesia dapat memiliki laboratorium pertanggalan "modern" tersebut. Dipilihnya spektrometer massa berbasis siklotron tersebut karena apabila menggunakan spektrometer massa akselerator harganya relatif mahal (sekitar US\$ 300 juta) ${ }^{(39)}$ dan membutuhkan ruang yang cukup luas, sehingga beaya pembangunannya kecil kemungkinannya untuk direalisasikan.

Pertanggalan ${ }^{210} \mathrm{~Pb}$ yang telah ditekuni saat ini perlu diperluas dan dilengkapi dengan analisis ${ }^{210} \mathrm{Po}$ dan ${ }^{137} \mathrm{Cs}$ untuk analisis laju sedimentasi, disamping itu perlu dikembangkan juga spektrometri gamma latar rendah karena tenaga ${ }^{210} \mathrm{~Pb}$ berada pada tenaga yang rendah. Perlu ditingkatkannya penelitian tentang prakiraan periodisasi terjadinya peningkatan dengan cepat timbulnya alga berbahaya (harmful algal bloom, HAB) yang sangat membahayakan lingkungan pada daerah-daerah tertentu di wilayah Indonesia.

\section{KESIMPULAN}

Didasarkan pada uraian di atas dapat disimpulkan bahwa pertanggalan radiokarbon dan pertanggalan ${ }^{210} \mathrm{~Pb}$ yang merupakan peran pertanggalan radiometris untuk kepentingan umum sangat bermanfaat untuk berbagai bidang. Beberapa cuplikan lingkungan di sekitar situs arkeologi maupun penelitian di situs geologi telah berhasil dilakukan analisis pertanggalan radiokarbon. Pertanggalan radiokarbon dapat juga memberikan kontribusi sebagai data dukung penelitian tentang paleotsunami, sehingga dapat digunakan untuk memperkirakan kemungkinan kapan terjadinya tsunami di masa mendatang, sedangkan untuk metode pertanggalan ${ }^{210} \mathrm{~Pb}$ telah dilakukan penelitian mengenai laju sedimentasi serta penelitian tentang keberadaan alga berbahaya (harmful algal bloom, $\mathrm{HAB}$ ) di dalam cuplikan sedimen yang sangat membahayakan lingkungan dan telah diteliti pada daerah-daerah tertentu.

Diharapkan pada tahun-tahun mendatang Indonesia dapat memiliki laboratorium pertanggalan radiokarbon "modern", yaitu peralatan spektrometer massa yang berbasis siklotron. Alat tersebut dengan pengembangan tertentu pada waktu mendatang selain untuk kepentingan analisis ${ }^{14} \mathrm{C}$ dapat juga dimanfaatkan untuk analisis kandungan berbagai isotop, sedangkan pertanggalan ${ }^{210} \mathrm{~Pb}$ dapat membantu penelitian tentang prakiraan periodisasi terjadinya peningkatan dengan cepat timbulnya alga berbahaya (harmful algal bloom, HAB) yang kemungkinan terjadinya mempunyai kecenderungan semakin meningkat, seiring dengan meningkatnya pencemaran lingkungan.

\section{DAFTAR PUSTAKA}

1. ANONIM., http://www.en.wikipedia.org/wiki/Radiometric_dating, Juli (2008).

2. WISJACHUDIN F., F. LAHAGU, DJOKO WIDODO, K.T.BASUKI, A.TAFTAZANI, SUCI WIDAYATI, Peranan Teknologi Nuklir Di Bidang Arkeologi Indonesia dan Pengembangannya , Berkala Arkeologi, Tahun XX Edisi No.1, ISSN 0216-1419 (2000) 141.

3. ANONIM.,http://www.en.wikipedia.org/wiki/ Radiocarbon_dating, Juli (2008).

4. T.HIGHAM.,http://www.c14dating.com/agecalc.html, Juli (2008).

5. T. HUTABARAT, "Penggunaan Isotop Pb-210 Untuk Identifikasi Proses Sedimentasi Di Muara: Studi Kasus Muara Sungai Minamura", Forum Nuklir Edisi Khusus, ISSN 1411-210

6. HENK HEIJNIS., "The Principle Of ${ }^{210} \mathrm{~Pb}$ Dating Of Sediments", Proceeding IAEA/RCA Regional Technical Workshop on RadiometricDating/Cyst Analysis Techniques and Receptor Binding Assay for Harmful Algal Bloom Management, ISBN 974-352-055-4 (2002), 1-16.

7. T.HIGHAM.,http://www.c14dating.com/k12.html, Juli ( (2008).

8. T.HIGHAM.,http://www.c14dating.com/int.html, Juli (2008). 
9. J.C., SHEPARD, Radiocarbon Dating Primer, Washington University Collage of Engineering Bulletin 338, Engineering Extention Service, Pullmen Washington, (1975).

10. WISJACHUDIN F., A.TAFTAZANI, M.E. BUDIONO, ROSYIDIN, SISWANTO, Peranan Pertanggalan Absolut Untuk Memberikan Solusi Permasalahan Situs Wonoboyo, Klaten Jawa Tengah, Jurnal Nusantara Kimia Vol.VIII, No.1, Januari 2001, ISSN 0854-6541, (2001) 49-52.

11. WISJACHUDIN, F.,"Perbandingan Penggunaan Pencacah kelip Cair Dengan Spektrometri Massa Akselerator Untuk Pertanggalan Radiokarbon", Prosiding Pertemuan dan Presentasi IImiah Teknologi Akselerator Dan Aplikasinya Vol.1 No.2 Desember 1999, Puslitbang Teknologi Maju-BATAN, Jogyakarta, ISSN 1411-1349, (1999).

12.R.A. MULLER, Radioisotope Dating with a Cyclotron, Science Vol. 196. no. 4289, (1977) 489 494

13. J.J., WELCH, et.al., A 40 keV cyclotron for radioisotope dating, Nuclear Instruments and Methods in Physics Research Section B, Volume 5, Issue 2, (1984) p. 230-232.

14. K.J., BERTSCHE, "A small low energy cyclotron for radioisotope measurements" Thesis (Ph.D.); DOE Project, Technical Report, http://www.osti.gov/ energycitations (2008).

15. WISJACHUDIN F., KRIS TRI BASUKI, BOY RAHARDJO SIDHARTA,"Studi Analisis Kista (Cyst) Harmful Algal Bloom" Prosiding PPI, Penelitian Dasar IImu Pengetahuan dan Teknologi Nuklir (PDIPTN), Puslitbang Teknologi Maju-BATAN, Jogyakarta, 12 Juli 2005, ISSN 0216-3128, (2005).

16. WISJACHUDIN, F., KRIS TRI BASUKI, BOY RAHARDJO SIDHARTA, PURNOMO RAHARDJO, Ecological Study On HAB Cyst In Cirebon Coastal Area, West Java Indonesia, Konflik Kepentingan Dalam Pengelolaan Sumber Daya Air, Penerbit BIGRAF Publishing Bekerjasama dengan Sekolah Tinggi Teknik Lingkungan (STTL) Yogyakarta, 2004, ISBN: 979-8680-66-X, (2004).

17. WISJACHUDIN F., A.TAFTAZANI, F. LAHAGU, SUMIYATNO, SUHARDI, I. PRAYOGO, WARTONO RAHARDJO, "Pengkajian Stratigrafi Cuplikan Batuan Dari Zaman Kuarter Menggunakan Pertanggalan Radiokarbon", Prosiding PPI, Penelitian Dasar Ilmu Pengetahuan dan Teknologi Nuklir, PPNY-BATAN, Yogyakarta, 25-27 April 1995, (1995) 239-244.

18. WISJACHUDIN F., A.TAFTAZANI, AGUS S., HELMY M., DJIONO, "Pertanggalan Radiokarbon Sebagai Salah Satu Data Dukung Pembuktian Keberadaan Danau Di Daerah Borobudur", Prosiding PPI, Penelitian Dasar IImu Pengetahuan dan Teknologi Nuklir, PPNY-BATAN, Yogyakarta, 8-10 Juli 1997, ISSN 0216-3128, (1997) 55-62.

19. ANONIM, Tsunami Purba Diteliti: Kawasan Pangandaran Pernah Merupakan Laguna, http://www.indonesia.go.id/ (2006).

20.MA'RUFIN S., Kawah Burkcle, al-Amarah dan Ambruknya Zaman Perunggu, http: //ekliptika. wordpress.com/2007/12/ (2007).

21. WISJACHUDIN F., A.TAFTAZANI, HARYONO AB., S. WIDAYATI, SUMIYATNO, SUHARDI, SISWANTO, DJIYONO, "Perbandingan Pertanggalan Absolut (Radiokarbon) Dan Relatif Candi Pringapus Dan Candi Gondosuli", Prosiding PPI, Penelitian Dasar Ilmu Pengetahuan dan Teknologi Nuklir, PPNY-BATAN, Yogyakarta, 23-25 April 1996, ISSN 0216-3128, (1996) 104-109.

22. WISJACHUDIN F., ROSYIDIN, SISWANTO, DARWIN A. SIREGAR, "Peranan Pertanggalan Absolut Untuk Mengetahui Komunitas Pada Era Candi Gedongsono" Prosiding PPI, Penelitian Dasar IImu Pengetahuan dan Teknologi Nuklir (PDIPTN), Puslitbang Teknologi Maju-BATAN, Jogyakarta, 7-8 Agustus 2001, ISSN 0216-3128 (2001) Buku II 50-56.

23. B.WASITO,WISJACHUDIN F., A.TAFTAZANI, K.T.BASUKI, SISWANTO, "Radiocarbon Dating At Sites Of Java and Central Java Provinces As supporting Data For The Temples Chronology In Indonesia" Proceeding of the $3^{\text {rd }}$ International Conference on Isotopes, ISOTOPE PRODUCTION AND APPLICATION IN THE 21 ST CENTURY"6-10 September 1999, Vancouver, Canada , World Scientific Publishing Co. Pte.Ltd. (1999) 308-310.

24. WISJACHUDIN F., ROSYIDIN, SUMIYATNO, SISWANTO, DARWIN A. SIREGAR, "Pertanggalan Radiokarbon Pada Situs Candi Jabung Salah Satu Candi Di Jawa Timur", Prosiding PPI, Penelitian Dasar Ilmu Pengetahuan dan Teknologi Nuklir (PDIPTN), Puslitbang Teknologi Maju-BATAN, Jogyakarta, 25-26 Juli 2000, ISSN 0216-3128 (2001) Buku II 187-192. 
25. WISJACHUDIN F., KRIS TRI BASUKI, A. TAFTAZANI, M.EKO BUDIONO, SISWANTO, "Perbandingan Pertanggalan Absolut Dan Relatif Pada Era Candi Kotes dan Kidal', Prosiding Seminar Nasional V Kimia dalam Pembangunan, JASA KIAI 26-27 Maret 2002, ISSN 0854-4778, (2002) 456-462.

26. WISJACHUDIN F., A.TAFTAZANI, SUMIYATNO, SISWANTO, DJIYONO, "Pertanggalan Radiokarbon Pada Situs Candi Tegowangi dan Sumberawan sebagai data dukung kronologi candi di Indonesia", Prosiding PPI, Penelitian Dasar Ilmu Pengetahuan dan Teknologi Nuklir, PPNY-BATAN, Yogyakarta, ISSN 0216-3128 (1998) Buku II 221-226.(1998)

27. WISJACHUDIN, F., SISWANTO, "Perbandingan Pertanggalan Absolut Dan Relatif Pada Era Candi Brahu", Prosiding Seminar Nasional IX Kimia Dalam Pembangunan, Temu IImiah JASA KIAI, ISSN 0854-4778, (2006).

28. WISJACHUDIN,F., SISWANTO, "Pertanggalan Radiokarbon Cuplikan Arang Di Daerah Song (Gua) Keplek Gunung Sewu", Prosiding Seminar Nasional X Kimia Dalam Pembangunan, Temu IImiah JASA KIAI, ISSN 0854-4778, (2007)

29. ANONIM,http://www.nationalgeographic.co.id/, (2008).

30. SUMINING, WISJACHUDIN F., SUDARMADJI., "Estimasi Kecepatan dan Pengendapan Di Pantai Cirebon Menggunakan Profil 210 Pb", Prosiding PPI, Penelitian Dasar IImu Pengetahuan dan Teknologi Nuklir, Puslitbang Teknologi Maju-BATAN, Jogyakarta, 13 Juli 2004, ISSN 0216-3128, (2002)

31. WISJACHUDIN,F., KRISTRI BASUKI, B.R. SIDHARTA, P.RAHARDJO, Ecological Study On HAB In Cirebon Coastal Area,West Java,Indonesia, Konflik Kepentingan Dalam Pengelolaan Sumber Daya Air, Penerbit BIGRAF Publishing Bekerjasama dengan Sekolah TinggiTeknik Lingkungan (STTL) Yogyakarta, 2004, ISBN: 979-8680-66-X, (2004).

32. WISJACHUDIN F., SUMINING, A.TAFTAZANI, , KRIS TRI BASUKI, I WAYAN LUGRA "Estimasi Kecepatan Dan Fluks Massa Sedimentasi Di Pantai Ciamis Selatan Menggunakan Metode ${ }^{210} \mathrm{~Pb}$ ", Prosiding PPI, Penelitian Dasar Ilmu Pengetahuan dan Teknologi Nuklir, Puslitbang Teknologi Maju-BATAN, Jogyakarta, 13 Juli 2004, ISSN 0216-3128, (2004)

33. BOY RAHARDJO SIDHARTA, WISJACHUDIN, F., KRIS TRI BASUKI, I WAYAN LUGRA "Analysis of Harmful Algal Bloom (HAB) In The Coastal Area Of South Ciamis", Second International Seminar on Environmental Chemistry and Toxicology (2nd InSECT) 2005, April 26-27, 2005 Jogjakarta, Indonesia, (2005).

34. SUMINING DAN SUKIRNO, "Laju Sedimentasi Dan Akumulasi Massa Sedimen Pantai Surabaya, Prosiding PPI - PDIPTN. ISSN 0216-3128 ( 2006).

35. KRIS TRI BASUKI, WISJACHUDIN, F, "COUNTRY REPORT", Proceeding IAEA/RCA Regional Technical Workshop on Radiometric Dating/Cyst Analysis Techniques and Receptor Binding Assay for Harmful Algal Blooms Management, Burapha University, Office of Atomic Energy for Peace, Thailand, ISBN 974-352-055-4 (2002) .

36. HENI S., A. A. LUBIS, YARIANTO SBS, FEPRIADI, SARMIN, "Aplikasi Tekik Uklir Untuk Studi Geokroologi Sedimen Di Perairan Patai Lokasi Tapak PLTN Ujung Lemahabang, Semenanjung Muria" Prosiding Seminar Nasional Teknologi Pengolahan Limbah VI, ISSN 1410-6086 (2004).

37. SUMINING, A.TAFTAZANI, N.ANISA., "Penggunaan Natrium Politungstat Untuk Indentifikasi Jenis Cyst Algae Beracun Di Semenanjung Muria", Prosiding PPI,PDIPTN, Puslitbang Teknologi Maju, BATAN Yogyakarta, issn 0216-3128 (2004) 480-488.

38. TENGKU DAHRIL, "Red Tide Di Teluk Jakarta Pertengahan September 1979", Terubuk VII No.20, ISSN 0126-4265 (1981) 1-12.

39. ANONIM.,http://www.radiocarbondating. com/, Juli (2008). 